\title{
Production and Evaluation of Bread Made from High Quality Cassava Flour (HQCF) and Wheat Flour Blends
}

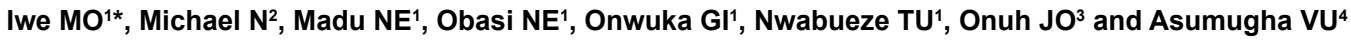 \\ ${ }^{1}$ Department of Food Science and Technology, Michael Okpara University of Agriculture, Umudike, P. M. B. 7267 Umuahia, Abia State, Nigeria \\ ${ }^{2}$ Department of Bioresource Engineering, Macdonald Campus of McGill University, Ste-Anne-de-Bellevue, Quebec H9X 3V9, Canada \\ ${ }^{3}$ Department of Food, Nutrition and Home Sciences, Kogi State University, P. M. B. 1008 Anyigba, Kogi State, Nigeria \\ ${ }^{4}$ Department of Human Nutrition and Dietetics, Michael Okpara University of Agriculture, Umudike, P. M. B. 7267 Umuahia, Abia State, Nigeria
}

\begin{abstract}
Bread prepared from blends of high quality cassava flour (HQCF) and wheat flour (WF) was evaluated to determine the suitability of HQCF as a partial replacement for wheat flour. Bread was prepared using ratios of $0: 100$, 10:90, 20:80, 30:70, 40:60 and 50:50 HQCF/WF respectively and assessed for their physicochemical, physical and sensory properties. The results showed that bread with higher levels of HQCF had higher moisture and carbohydrates content but lower ash, fat and fibre contents. The moisture content significantly varied from 28.51 to $35.01 \%$. The high moisture content of the HQCF replaced bread samples may be attributed to the higher carbohydrates (starch) which has tendency for water uptake and retention. This is evidenced by the higher loaf weight and loaf density of the HQCF replaced bread samples. However, loaf volume and oven spring were negatively affected by increased incorporation of HQCF in bread, suggesting that the low protein content of HQCF may be responsible. The results of the sensory evaluation revealed that replacement of wheat flour with HQCF beyond $10 \%$ negatively affected sensory attributes, supplementation levels between $20-30 \%$ were tolerated by the panelists. It is therefore concluded that HQCF can be used as a potential replacement for wheat flour in the baking of bread.
\end{abstract}

Keywords: Cassava flour; Bread; Sensory attributes; Wheat flour; Supplementation; Blends

\section{Introduction}

In the recent years there has been an increasing demand for wheatbased convenient foods in many developing countries attributed to an ever-increasing population and changing eating habits. Efforts have been initiated in several of these developing countries to promote the use of composite flours for baking [1]. Here, a fraction of wheat flour is replaced by flour from locally grown crops such as cassava, yams, sweet potatoes, bananas etc., [2,3]. For certain products, attempts have been made to completely substitute wheat flour with other flours and entirely alter their recipes [4]. Previously, some of these composite flours have been applied without any prior knowledge of their performance in food systems, resulting in products with varying degrees of consumer acceptability. The possibility of using starchy tubers, cereals and fruits and vegetables instead of wheat flour in foods depends on their chemical and physical properties. Amylose/amylopectin ratio, for example, influences the flour's behavior in food systems such as viscosity, gelatinization and setback which affect the texture of the end product $[2,3,5]$.

Bread is a staple food prepared from dough of flour and water, usually by baking. Throughout recorded history, bread has been very popular around the world. It is one of humanity's oldest foods, having been of great importance since the dawn of Agriculture [3,6]. In Nigeria, it is one of the most widely consumed food sources. In 2005 and 2012, the Federal Government of Nigeria mandated the use of composite wheat flour for baking through the addition of $10 \%$ cassava flour to wheat, in order to cut down on the expense on wheat importation and find more value addition for the widely-produced cassava tubers [7]. Acceptability of cassava flour bread is generating a lot of attention among researchers, agricultural administrators, farmers, industrialists and consumers in Nigeria owing to cheap cost, availability and affordability. As a result, there are different types, shapes, sizes, and textures of breads in various regions [3].
High quality cassava flour (HQCF) offers a viable alternative for wheat flour replacement. However, it must meet the quality requirements in terms of physicochemical characteristics, microbial safety and cyanogenic glucoside content [5]. According to Iwe et al. [2], there are presently several improved cultivars of cassava developed at National Root Crops Research Institute (NRCRI), Umudike and the International Institute of Tropical Agriculture (IITA), Ibadan both in Nigeria that are relatively high in dry matter and starch contents that meet these requirements. High quality cassava flour (HQCF), has been reported to be suitable for several applications at household level, for making a variety of pastries and convenience foods at urban centers and acceptable raw materials for the manufacture of industrial items [2]. This is necessitated by the astronomical rise in the price of wheat in the global market as well the need to promote the utilization of local sources of flour for partial substitution of wheat flour in the baking industries. Therefore, the objective of this study was to assess the bread making potentials of composite flours made from HQCF by determining the physicochemical, physical and sensory properties of bread made from HQCF/wheat flour blends.

\section{Materials and Methods}

\section{Materials}

Cassava roots TME 419, TMS 98/1632, TMS 98/87164, TMS

*Corresponding author: Iwe MO, Department of Food Science and Technology, Michael Okpara University of Agriculture, Umudike, P. M. B. 7267 Umuahia, Abia State, Nigeria, Tel: +2348035487198; E-mail: maduoiwe@yahoo.com

Received March 01, 2017; Accepted September 28, 2017; Published October 05, 2017

Citation: Iwe MO, Michael N, Madu NE, Obasi NE, Onwuka GI, et al. (2017) Production and Evaluation of Bread Made from High Quality Cassava Flour (HQCF) and Wheat Flour Blends. Agrotechnology 6: 166. doi: 10.4172/2168-9881.1000166

Copyright: (c) 2017 Iwe MO, et al. This is an open-access article distributed under the terms of the Creative Commons Attribution License, which permits unrestricted use, distribution, and reproduction in any medium, provided the original author and source are credited. 
98/8082, and TMS 98/0581 used were obtained from National Root Crops Research Institute, Umudike, Abia State, Nigeria. All-purpose wheat flour (Dangote Groups, Nig. Ltd, Lagos, Nigeria) used was obtained from Umuahia main market at Ubani Ibeku in Abia state, Nigeria.

\section{Methods}

Production of high quality unfermented cassava flour: The roots were processed into High Quality cassava flour using the method described by IITA [8]. The fresh root cassava was weighed with Avery Birmingham weighing balance and then peeled manually using stainless knife. The peeled cassava samples were then washed with portable water and weighed to determine percentage yield after peeling. The cleaned tubers were later transferred to a grating machine which grated the cassava tubers to slurry/mash. The mash was dewatered using hydraulic presser to about $40 \%$ moisture. The cake was pulverized and subjected to drying in an oven (Uniscope SM9023) set at temperature $1000^{\circ} \mathrm{C}$ and dried to $8-10 \%$ moisture level. After drying, the cake was milled using hammer mills (power crusher F-23ZS111). The fine High Quality Cassava Flour (HQCF) thus obtained was packed in a highdensity polyethylene bags, awaiting use.

Formulation of HQCF-wheat flour blends: Composite flours of high quality cassava flour (HQCF) and wheat flour were formulated in the following ratios; $0 \%$ and $100,10 \%$ and $90 \%, 20 \%$ and $80 \%, 30 \%$ and $70 \%, 40 \%$ and $60 \%$ and $50 \%$ and $50 \%$ respectively and subsequently used for bread baking.

Baking of bread with HQCF/wheat composite flours: All ingredients were initially dry mixed in a bowl and later water was mixed with the original dry mix until soft dough that could easily be handled was produced. The straight dough method described by Eggleston et al. [9] was followed. The dough was manually kneaded before molding into shapes. Dough proofing was carried out for the different proofing time at room temperature and baked at $2100^{\circ} \mathrm{C}$ for $25 \mathrm{~min}$. After baking, the dough was brought out in each case from the oven and immediately depanned by knocking out. The knocked-out bread was then placed on a wooden table to cool and to avoid condensation.

\section{Analyses of samples:}

Proximate analyses of bread from blends of HQCF and wheat flour: The moisture content of the bread baked from HQCF and wheat flour blends was determined by drying the sample in a forced Genlab (Widnes, England) air oven at $1050^{\circ} \mathrm{C}$ according to the guidelines of AOAC [10]. Crude protein ( $\mathrm{N}$ x 6.25) was estimated through Kjeltec apparatus according to the protocol of AOAC [10] methods. Crude fat content of the bread samples was estimated using hexane as solvent in a soxtec system as described in AACC [11] methods. Total ash content was estimated by direct incineration of dried samples in a muffle furnace at $550^{\circ} \mathrm{C}$ according to the method of AACC [11]. Crude fibre content was determined by digesting the fat free samples in $1.25 \%$ $\mathrm{H}_{2} \mathrm{SO}_{4}$ followed by $1.25 \% \mathrm{NaOH}$ using Labconco fibretech apparatus according to AACC [11] methods. Total carbohydrate content was calculated by difference according to Ihekoronye and Ngoddy [12] using the equation;

Total carbohydrate $=100-($ moisture + crude protein + crude fat + crude fibre + ash)

Physical characteristics of bread baked from composites of HQCF/ wheat flour: The bread characteristics or baking qualities were evaluated by measuring the loaf volume, the loaf weight, the loaf specific volume, the oven spring and the organoleptic properties of the bread samples.
Loaf weight: Loaf weight was determined using the method of AACC [11], Loaf weight of the bread was determined after sufficient (50 min) cooling using a digital balance ( $0.01 \mathrm{~g}$ accuracy) and the values were recorded.

Loaf volume: Loaf volume of each bread sample was measured 50 minutes after the loaves were removed from the oven by using the rapeseed displacement method as described by Onwuka [13]. Millet seeds were used in place of rape-seed. The weight of each of the bread samples was weighed with the aid of a weighing balance. This was then followed by taking the volume of the container from the graduation on its body which was recorded as V1 $\left(\mathrm{cm}^{3}\right)$. The container was then filled with 4-5 volume of the loaf sample with the seeds until the seed dropping from a height of $1 / 2$ foot above the container rim is cut-off such that the seeds formed a Plateau with the rim of the container. They were then poured out, weighed and recorded as W1 (g). The weight of the seeds that filled the container was equivalent to the total weight of seed that completely occupied the volume of the container. Then, $1 / 3$ of the volume of the container was filled with the seeds, the loaf in each case laid flat at the centre of the container and then the remaining seeds used to fill up the container to overflow from $1 / 2$ foot above the container. With a ruler, the seeds above the rim were cut off as they formed, plateau with the container. The seeds displaced by the loaf in each case were collected, weighed and recorded as W2 (g). This weight of seeds corresponded to the volume of space displaced by the loaf sample in each case placed in the container. The loaf volume for each bread sample was calculated as;

Loaf volume $=\mathrm{W} 2 \times \mathrm{V} 1 / \mathrm{W} 1$

Where $\mathrm{W} 1$ = weight of seeds that filled the container

W2 = weight of seeds displaced by the loaf sample

$\mathrm{V} 1=$ volume of the container

Specific loaf volume: The specific loaf volume was determined using the method described by Onwuka [13]. The specific loaf volume for each sample was determined by dividing the loaf volume of each sample with the corresponding loaf weight thus;

Specific loaf volume $=$ loaf volume $\left(\mathrm{cm}^{3} / \mathrm{g}\right) /$ loaf weight .

Oven spring: The oven spring for each bread sample was determined from the differences in height of dough before and after baking [13].

Crumb moisture: The moisture content of bread sample was calculated using approved method [11] by drying two grams of bread samples in an air oven at $1050^{\circ} \mathrm{C}$ to constant weight. The samples were dried until constant weight was obtained.

Sensory evaluation of bread samples: Sensory evaluation was carried out using a 25-man panelist to assess the organoleptic attributes (taste, crumb appearance, crust appearance, softness of feel/texture, bread height and volume and overall acceptability) of the bread samples [14]. The panelists were selected randomly from the staff and students of the Michael Okpara University of Agriculture, Umudike, Nigeria. They were made to carry out the organoleptic assessment under controlled environment to avoid biased results. In the questionnaire, the panelists were required to observe and test each coded sample and grade them using ranking preference test. Potable water was provided for them to rinse their mouth in between evaluations. The bread samples placed in disposable plates were presented in small slices and coded on identical white papers. The panelists were instructed to rank the samples based on the highly-preferred sample in order of $1,2,3,4$ and 5 where the most preferred has the rank one (1) and least preferred with the rank 5. The raw scores were assembled and statistically analyzed using the method described by Iwe [14]. 
Citation: Iwe MO, Michael N, Madu NE, Obasi NE, Onwuka GI, et al. (2017) Production and Evaluation of Bread Made from High Quality Cassava Flour (HQCF) and Wheat Flour Blends. Agrotechnology 6: 166. doi: 10.4172/2168-9881.1000166

Page 3 of 8

\section{Statistical analysis}

Results of all determinations were expressed as means of triplicate values. Data were subjected to one-way Analysis of Variance (ANOVA) and significant differences detected using Tukey's test. An IBM SPSS Statistical package (version 20.0) was used for all statistical analyses.

\section{Results and Discussion}

\section{Results of proximate analysis on the bread samples}

Proximate analysis revealed that all bread from blended flour (HQCF) and wheat flour had comparable moisture values (Table 1). Moisture content of the bread ranged from 28.51 to $35.01 \%$ with sample A2070 having the highest values while samples D5080 and D5070 had the least values. Moisture content is an important attribute in food processing and preservation because many biochemical and physiological changes depend very much on it [13]. Sample C1050, A1040 and wheat had the similar moisture content values showing no significance $(\mathrm{p}>0.05)$ among them. The high moisture content of the bread sample (28.51-35.01\%) may be attributed to the amount of water added during baking as cassava flour tends to absorb more water than wheat flour [15]. The results however are in accordance with the observation by Nwosu et al. [16] that bread made with cassava flour tends to retain more moisture than with wheat flour (Table 1).

NB; A2080=TMS419,20\% composite and $80 \mathrm{~min}$, B5080 $=$ TMS98/0581, 50\% composite and $80 \mathrm{~min}$ proofing, C3080 $=$ TMS $98 / 1632,30 \%$ composite and 80 min proofing, D5080=TMS 98/8082,50\%compositeand 80 min proofingtime,E5080=TMS98/87164, $50 \%$ composite and 80 min proofing, C2070=TMS 98/1632, $20 \%$ composite and 70 min proofing, E4070=TMS98/87164, 40\% composite and 70 min proofing, B5070=TMS $98 / 0581,50 \%$ composite and 70 min proofing, A2070=TME 419, 20\% composite and 70 min proofing, D5070 $=$ NR98 $/ 8082,50 \%$ composite and 70 min proofing, A2060=TME 419, 20\% composite and $60 \mathrm{~min}$ proofing, D4060=NR98/8082, 40\% composite and 60 min proofing, B4060=TMS98/0581, 40\% composite and $60 \mathrm{~min}$ proofing, C2060 $=$ TMS $98 / 1632,20 \%$ composite and $60 \mathrm{~min}$ proofing, E3060=TMS $98 / 87164,30 \%$ composite and 60 mins proofing time, E2050 = TMS $98 / 87164,20 \%$ composite and 50 min proofing, B4050=TMS 98/0581, 40\% composite and 50 min proofing, D2050=NR 98/8082, 20\% composite and 50 min proofing, A1050=TMS 419, 10\% composite and 50 min proofing, C1050=TMS 98/1632, 10\% composite and 50 min proofing, E1040=TMS 98/87164, 10\% composite and 40 min proofing, A1040=TMS 419, 10\% composite and $40 \mathrm{~min}$ proofing, D3040=NR 98/8082, 30\% composite and 40 min proofing, B3040 $=$ TMS $98 / 0581,30 \%$ composite and $40 \mathrm{~min}$ proofing, $\mathrm{C} 1040=$ TMS 98/1632, 10\% composite and 40 min proofing.

The protein content of the bread sample significantly ranged from 3.02-9.73\% with sample B5080 having the least protein content and wheat having the highest. The increase in the level of substitution of cassava flour reduces the protein content of the bread sample as cassava flour do not contain gluten protein which is the protein in wheat flour responsible for dough extensibility and elasticity [17,18]. The high protein content of $100 \%$ wheat bread is an indication that wheat is a better source of protein compared to cassava, a non-protein tuber. It is

\begin{tabular}{|c|c|c|c|c|c|c|}
\hline Sample & Moisture (\%) & Protein (\%) & Crude fat (\%) & Crude fibre (\%) & Ash (\%) & $\mathrm{CHO}(\%)$ \\
\hline E1040 & $33.00^{\text {cd }} \pm 0.01$ & $8.07^{e} \pm 0.23$ & $7.18^{d} \pm 0.01$ & $1.28^{n} \pm 0.01$ & $1.13^{m} \pm 0.01$ & $49.33^{h} \pm 0.28$ \\
\hline C1040 & $32.50^{d} \pm 0.14$ & $8.85^{b} \pm 0.12$ & $7.25^{c} \pm 1.34$ & $1.12^{q} \pm 0.01$ & $1.37^{b} \pm 0.01$ & $50.03^{g} \pm 0.44$ \\
\hline A1050 & $30.50^{f} \pm 0.03$ & $9.18^{b} \pm 0.34$ & $7.28^{b} \pm 0.01$ & $1.25^{\circ} \pm 0.01$ & $1.46^{\mathrm{j}} \pm 0.71$ & $50.33^{g} \pm 0.08$ \\
\hline A1040 & $32.52^{d} \pm 0.02$ & $8.30^{d} \pm 0.03$ & $7.04^{e} \pm 0.01$ & $1.21^{p} \pm 0.01$ & $1.85^{f} \pm 0.04$ & $49.49^{h} \pm 0.37$ \\
\hline C1050 & $32.01^{\text {cd }} \pm 0.01$ & $8.32^{d} \pm 0.01$ & $6.98^{\mathrm{de}} \pm 0.02$ & $1.13^{q} \pm 0$ & $1.76^{g} \pm 0$ & $49.80^{\mathrm{h}} \pm 0.04$ \\
\hline A2070 & $35.01^{a} \pm 0.01$ & $7.01^{g} \pm 0.58$ & $6.01^{i} \pm 0.07$ & $1.35^{\prime} \pm 0$ & $1.07^{p} \pm 0.02$ & $49.55^{h} \pm 0.65$ \\
\hline A2060 & $31.51^{\mathrm{e}} \pm 0.03$ & $7.60^{f} \pm 0.06$ & $6.65^{f} \pm 0.01$ & $1.29^{n} \pm 0$ & $1.33^{\prime} \pm 0.01$ & $51.62^{\mathrm{e}} \pm 0.07$ \\
\hline E2050 & $32.02^{\mathrm{cd}} \pm 0.02$ & $7.59^{f} \pm 0.28$ & $6.11^{i} \pm 0.04$ & $1.35^{n} \pm 0.01$ & $1.53^{i} \pm 0.01$ & $51.40^{\mathrm{e}} \pm 0.07$ \\
\hline $\mathrm{C} 2060$ & $33.50^{c} \pm 0.01$ & $6.38^{j} \pm 0.4$ & $6.25^{g} \pm 0$ & $1.25^{\circ} \pm 0.01$ & $1.06^{p} \pm 0.03$ & $51.56^{e} \pm 0.43$ \\
\hline C2070 & $34.50^{b} \pm 0.01$ & $6.12^{m} \pm 0.04$ & $6.18^{\mathrm{h}} \pm 0.02$ & $1.32^{n} \pm 0.01$ & $0.83^{q} \pm 0.01$ & $51.05^{\dagger} \pm 0.04$ \\
\hline D2050 & $34.00^{b} \pm 0.03$ & $6.51^{i} \pm 0.28$ & $5.39^{\prime} \pm 0.01$ & $1.31^{n} \pm 0.01$ & $1.29^{\prime} \pm 0.01$ & $51.50^{\mathrm{e}} \pm 0.25$ \\
\hline A3080 & $30.51^{f} \pm 0.04$ & $6.16^{\prime} \pm 0.03$ & $5.28^{n} \pm 0.03$ & $1.44^{j} \pm 0$ & $1.86 \pm 0$ & $54.75^{d} \pm 0.03$ \\
\hline B3040 & $30.51^{f} \pm 0.01$ & $6.38^{j} \pm 0$ & $5.63^{k} \pm 0.01$ & $2.20^{e} \pm 0.02$ & $1.10^{\circ} \pm 0.02$ & $54.18^{d} \pm 0.04$ \\
\hline C3080 & $31.00^{\mathrm{e}} \pm 0.14$ & $6.22^{k} \pm 0.01$ & $5.31^{\mathrm{m}} \pm 0.02$ & $1.41^{\mathrm{k}} \pm 0.02$ & $1.85^{f} \pm 0.01$ & $54.21^{d} \pm 0.05$ \\
\hline D3040 & $31.01 \pm 0.01$ & $6.61^{\mathrm{h}} \pm 0.01$ & $5.09^{n} \pm 0.31$ & $1.33^{m} \pm 0$ & $1.16^{m n} \pm 0$ & $54.80^{d} \pm 0.14$ \\
\hline E3060 & $31.02^{\mathrm{e}} \pm 0.02$ & $5.33^{\circ} \pm 0$ & $5.95^{j} \pm 0.07$ & $1.47^{i} \pm 0$ & $1.93^{e} \pm 0.01$ & $54.30^{d} \pm 0.02$ \\
\hline B4050 & $3 \pm 0.50^{f} \pm 0.02$ & $5.25^{\circ} \pm 0.23$ & $4.35^{q} \pm 0$ & $2.41^{d} \pm 0.01$ & $1.66^{\mathrm{h}} \pm 0.01$ & $55.53^{c} \pm 0.46$ \\
\hline B4060 & $30.05^{\mathrm{fg}} \pm 0.01$ & $5.00^{r} \pm 0.08$ & $4.96^{\text {no }} \pm 0$ & $2.49^{c} \pm 0.01$ & $2.16^{d} \pm 0.01$ & $55.34^{c} \pm 0.14$ \\
\hline E4070 & $30.51^{f} \pm 0.02$ & $5.63^{m n} \pm 0.8$ & $4.42^{p} \pm 0.04$ & $1.54^{h} \pm 0.01$ & $2.10^{d} \pm 0.03$ & $55.80^{\mathrm{bc}} \pm 0.84$ \\
\hline D4060 & $30.58^{\text {ef }} \pm 0.04$ & $5.53^{\mathrm{mn}} \pm 0.08$ & $4.92^{m n} \pm 0$ & $1.41^{k} \pm 0$ & $2.27^{c} \pm 0.02$ & $55.29^{c} \pm 0.38$ \\
\hline B5080 & $30.51^{f} \pm 0.02$ & $3.02^{r} \pm 0.01$ & $2.28^{r} \pm 0.02$ & $3.17^{a} \pm 0.01$ & $2.35^{\mathrm{a}} \pm 0.01$ & $57.67^{b} \pm 0.08$ \\
\hline B5070 & $30.50^{f} \pm 0.07$ & $\begin{array}{l}3.13^{r} \\
\pm 0.23\end{array}$ & $2.25^{r} \pm 0$ & $3.09^{b} \pm 0.01$ & $2.30^{\mathrm{b}} \pm 0.01$ & $58.75^{\mathrm{a}} \pm 0.01$ \\
\hline D5080 & $28.51^{g}$ & $4.44^{\mathrm{p}} \pm 0.03$ & $4.59^{\circ} \pm 0.01$ & $1.68^{f} \pm 0.01$ & $2.23^{c} \pm 0$ & $58.56^{a} \pm 0.36$ \\
\hline D5070 & $28.51^{g} \pm 0.03$ & $4.27^{q} \pm 0.03$ & $4.24^{q} \pm 0$ & $1.60^{g} \pm 0.01$ & $2.12^{d} \pm 0$ & $58.96^{a} \pm 0.11$ \\
\hline E5080 & $30.00^{\text {ef }} \pm 0.01$ & $4.26^{a} \pm 0.04$ & $4.21^{q} \pm 0.07$ & $1.67^{\mathfrak{f}} \pm 0.02$ & $2.20^{c} \pm 0.03$ & $57.66^{b} \pm 0.07$ \\
\hline W100 & $32.51^{d} \pm 0.01$ & $9.73^{\mathrm{a}} \pm 0.4$ & $7.62^{\mathrm{a}} \pm 0.01$ & $0.83^{r} \pm 0.01$ & $1.37^{\mathrm{k}} \pm 0.01$ & $48.26^{i} \pm 2.6$ \\
\hline LSD & 0.08 & 0.08 & 0.084 & 0.06 & 0.065 & 0.057 \\
\hline
\end{tabular}


Citation: Iwe MO, Michael N, Madu NE, Obasi NE, Onwuka GI, et al. (2017) Production and Evaluation of Bread Made from High Quality Cassava Flour (HQCF) and Wheat Flour Blends. Agrotechnology 6: 166. doi: 10.4172/2168-9881.1000166

Page 4 of 8

also evident from the result that increasing level of wheat flour increased the level of protein in cassava-wheat flour composite bread [17]

The fat content of the bread samples significantly ranged from 2.25 to $7.62 \%$ with sample B5080 (TMS98/0581, 50\% composite and 80 min proofing) having the least fat content (Table 2), while $100 \%$ wheat bread had the highest fat content. The increase in substitution level of cassava flour caused a decrease in the fat content of the bread sample suggesting that cassava tuber is not an oil rich crop. The crude fibre content showed a significant $(\mathrm{p}<0.05)$ difference between breads made from $100 \%$ wheat flour and B5070. It was observed that the crude fibre content of the bread samples (especially samples B3040, B4050, B4060, B5070 and B5080) increased with increased substitution level of cassava flour with a particular cassava variety, TMS 98/0581, suggesting that TMS 98/0851 is a good source of crude fibre, probably occasioned by a genetic improvement [17]. Crude fibre indicates materials that are indigestible to human digestive enzymes. Indigestible fibres are known to be beneficial to colon health as they improve bulk, delays gastric emptying and modulate intestinal inflammations. The ash content of the bread samples significantly ranged from $1.37-2.55 \%$ with $100 \%$ wheat bread having the least ash content. This range agrees with ash content specification reported by Abass et al. [19]. Ash content of samples give a general overview of its inorganic mineral content. There was significant difference $(\mathrm{p} \leq 0.05)$ among the blends except samples D5070, E4070 and B4060 which showed no significance ( $p>0.05)$. Bread made with higher substitution level of cassava flour recorded higher carbohydrate scores compared to lower substitutions and 100\% wheat flour. This is an indication that cassava tubers are good sources of carbohydrate compared to wheat and the composition produced blends with higher carbohydrate contents than the parent samples.

\section{Physical properties of bread made from HQCF and wheat flour blends}

Results of the effects of cassava variety, flour composition and proofing time on the physical properties of bread are shown in Table 2.

NB; A2080=TMS419,20\% composite and $80 \mathrm{~min}, \mathrm{~B} 5080=\mathrm{TMS} 98 / 0581$, $50 \%$ composite and $80 \mathrm{~min}$ proofing, C3080 $=$ TMS $98 / 1632,30 \%$ composite and 80 min proofing, D5080= TMS 98/8082, 50\% composite and $80 \mathrm{~min}$ proofing time, $\mathrm{E} 5080=\mathrm{TMS} 98 / 87164,50 \%$ composite and $80 \mathrm{~min}$ proofing, C2070 $=$ TMS 98/1632, 20\% composite and 70 min proofing, E4070= TMS98/87164, 40\% composite and $70 \mathrm{~min}$ proofing, B5070= TMS98/0581, $50 \%$ composite and 70 min proofing, A2070=TME $419,20 \%$ composite and 70 min proofing, D5070 = NR98/8082, 50\% composite and $70 \mathrm{~min}$ proofing, A2060 $=$ TME 419, 20\% composite and 60 min proofing, $\mathrm{D} 4060=$ NR98/8082, 40\% composite and 60 min proofing, B4060=TMS98/0581, $40 \%$ composite and $60 \mathrm{~min}$ proofing, C2060=TMS98/1632, $20 \%$ composite and 60 min proofing, E3060= TMS98/87164, 30\% composite and 60 mins proofing time, E2050 $=$ TMS $98 / 87164,20 \%$ composite and 50 minproofing, B4050=TMS $98 / 0581,40 \%$ composite and 50 min proofing, D2050 $=$ NR 98/8082, 20\% composite and 50 min proofing, A1050 $=$ TMS 419, 10\%composite and 50 min proofing, C1050= TMS 98/1632, 10\% composite and 50 min proofing, E1040= TMS 98/87164, 10\% composite and 40 min proofing, A1040= TMS 419, 10\% composite and $40 \mathrm{~min}$ proofing, D3040=NR 98/8082, 30\% composite and $40 \mathrm{~min}$ proofing, B3040 $=$ TMS98 $/ 0581,30 \%$ composite and $40 \mathrm{~min}$ proofing, $\mathrm{C} 1040=\mathrm{TMS}$ 98/1632, 10\% composite and 40 min proofing.

\section{Specific volume}

The specific volume ranged from 2.26 to $4.94 \mathrm{~cm}^{3} / \mathrm{g}$ with $10 \%$ TMS

\begin{tabular}{|c|c|c|c|c|c|c|}
\hline Sample & $\begin{array}{l}\text { Specific volume } \\
\left(\mathrm{cm}^{3}\right) / \mathrm{g}\end{array}$ & $\begin{array}{l}\text { Loaf volume } \\
\qquad\left(\mathrm{cm}^{3}\right)\end{array}$ & $\begin{array}{l}\text { Weight } \\
\text { (g) }\end{array}$ & $\begin{array}{l}\text { Loaf density } \\
\left(\mathrm{g} / \mathrm{cm}^{3}\right)\end{array}$ & $\begin{array}{l}\text { Moisture } \\
(\%)\end{array}$ & Oven spring $(\mathrm{cm})$ \\
\hline A3080 & $2.78^{\prime} \pm 0.08$ & $410^{n} \pm 0.01$ & $147.64^{g} \pm 0.03$ & $0.36^{i} \pm 0.01$ & $29.50^{g} \pm 0.08$ & $0.2^{\mathrm{d}} \pm 0.00$ \\
\hline B5080 & $2.46^{n} \pm 0.15$ & $390^{p} \pm 0.06$ & $158.54^{a} \pm 0.05$ & $0.40^{f} \pm 0.02$ & $24.60^{\prime} \pm 0.15$ & 0 \\
\hline C3080 & $2.59^{m} \pm 0.01$ & $425^{m} \pm 0.02$ & $158.54^{a} \pm 0.05$ & $0.39^{9} \pm 0.08$ & $31.00^{\mathrm{e}} \pm 0.05$ & 0 \\
\hline D5080 & $2.05^{q} \pm 0.03$ & $324^{t} \pm 0.05$ & $157.82^{b} \pm 0.01$ & $0.49^{b} \pm 0.03$ & $28.50^{h} \pm 0.11$ & $-0.5^{i} \pm 0.0$ \\
\hline E5080 & $2.28^{p} \pm 0.01$ & $343^{s} \pm 0.01$ & $150.18^{f} \pm 0.03$ & $0.44^{\mathrm{c}} \pm 0.01$ & $32.50^{d} \pm 0.02$ & $-0.45^{\mathrm{h}} \pm 0$ \\
\hline C2070 & $3.78^{g} \pm 0.02$ & $570^{f} \pm 0.11$ & $150.86^{f} \pm 0.03$ & $0.27^{n} \pm 0.05$ & $26.50^{j} \pm 0.11$ & $-0.9^{\prime} \pm 0.0$ \\
\hline E4070 & $2.60^{m} \pm 0.01$ & $365^{q} \pm 0.03$ & $140.19^{\prime} \pm 0.01$ & $0.38^{h} \pm 0.13$ & $26.50^{j} \pm 0.11$ & $-0.4^{h} \pm 0.0$ \\
\hline B5070 & $1.96^{r} \pm 0.10$ & $305^{\mathrm{u}} \pm 0.08$ & $155.70^{c} \pm 0.06$ & $0.51^{\mathrm{a}} \pm 0.00$ & $30.50^{f} \pm 0.04$ & $-0.7^{j} \pm 0.0$ \\
\hline A2070 & $2.99^{k} \pm 0.13$ & $425^{m} \pm 0.02$ & $142.10^{j} \pm 0.12$ & $0.33^{k} \pm 0.11$ & $35.00^{\mathrm{a}} \pm 0.11$ & $-0.8^{k} \pm 0.0$ \\
\hline D5070 & $2.34^{\circ} \pm 0.11$ & $345^{s} \pm 0.01$ & $147.50^{g} \pm 0.03$ & $0.43^{d} \pm 0.10$ & $31.00^{\mathrm{e}} \pm 0.05$ & $-0.9^{\prime} \pm 0.0$ \\
\hline A2060 & $3.32^{\mathrm{h}} \pm 0.05$ & $485^{j} \pm 0.06$ & $146.31^{h} \pm 0.02$ & $0.30^{m} \pm 0.10$ & $31.50^{\mathrm{e}} \pm 0.05$ & $-0.5^{i} \pm 0.0$ \\
\hline D4060 & $2.40^{n} \pm 0.15$ & $360^{r} \pm 0.11$ & $150.21^{f} \pm 0.03$ & $0.42^{\mathrm{c}} \pm 0.01$ & $29.59^{g} \pm 0.08$ & $-0.5^{i} \pm 0.0$ \\
\hline B4060 & $2.60^{m} \pm 0.01$ & $390^{p} \pm 0.06$ & $150.20^{f} \pm 0.03$ & $0.39^{9} \pm 0.08$ & $26.00^{j} \pm 0.11$ & $-0.3^{g} \pm 0.0$ \\
\hline C2060 & $3.97^{f} \pm 0.01$ & $560^{h} \pm 0.13$ & $141.15^{k} \pm 0.11$ & $0.25^{\circ} \pm 0.03$ & $29.00^{g} \pm 0.08$ & $-0.55^{i} \pm 0$ \\
\hline E3060 & $3.04 \pm 0.03$ & $445^{\prime} \pm 0.03$ & $146.54^{h} \pm 0.02$ & $0.33^{k} \pm 0.11$ & $31.00^{\mathrm{e}} \pm 0.05$ & $-0.2^{f} \pm 0.1$ \\
\hline E2050 & $4.19^{d} \pm 0.05$ & $615^{d} \pm 0.01$ & $146.94^{h} \pm 0.02$ & $0.24^{p} \pm 0.10$ & $32.00^{d} \pm 0.08$ & $0.2^{d} \pm 0.00$ \\
\hline B4050 & $2.26^{p} \pm 0.01$ & $400^{\circ} \pm 0.05$ & $152.58^{d} \pm 0.00$ & $0.38^{h} \pm 0.13$ & $33.50^{c} \pm 0.10$ & $0.1^{e} \pm 0.05$ \\
\hline D2050 & $3.72^{p} \pm 0.02$ & $545^{i} \pm 0.04$ & $146.50^{\mathrm{h}} \pm 0.02$ & $0.27^{n} \pm 0.05$ & $25.00^{k} \pm 0.13$ & $0.8^{a} \pm 0.02$ \\
\hline A1050 & $4.24^{c} \pm 0.10$ & $595^{\mathrm{e}} \pm 0.03$ & $140.43^{\prime} \pm 0.01$ & $0.24^{p} \pm 0.10$ & $30.50^{f} \pm 0.04$ & $0.7^{b} \pm 0.01$ \\
\hline C1050 & $4.02^{f} \pm 0.01$ & $565^{9} \pm 0.08$ & $140.70^{\prime} \pm 0.01$ & $0.25^{\circ} \pm 0.03$ & $19.00^{m} \pm 0.13$ & $0.7^{b} \pm 0.01$ \\
\hline E1040 & $4.94^{\mathrm{a}} \pm 0.03$ & $702^{a} \pm 0.03$ & $142.12^{j} \pm 0.12$ & $0.20^{r} \pm 0.03$ & $33.00^{c} \pm 0.10$ & $0.7^{b} \pm 0.01$ \\
\hline A1040 & $4.67^{b} \pm 0.05$ & $675^{b} \pm 0.11$ & $144.46^{i} \pm 0.08$ & $0.21^{a} \pm 0.11$ & $27.50^{i} \pm 0.08$ & $0.7^{b} \pm 0.01$ \\
\hline B3040 & $3.25^{i} \pm 0.11$ & $470^{k} \pm 0.01$ & $144.79^{i} \pm 0.08$ & $0.31^{\prime} \pm 0.05$ & $34.50^{b} \pm 0.13$ & $0.1^{\mathrm{e}} \pm 0.05$ \\
\hline D3040 & $2.92^{k} \pm 0.13$ & $445^{\prime} \pm 0.03$ & $152.60^{d} \pm 0.00$ & $0.34^{i} \pm 0.05$ & $30.50^{f} \pm 0.04$ & $0.2^{\mathrm{d}} \pm 0.00$ \\
\hline C1040 & $4.11^{\mathrm{e}} \pm 0.13$ & $623^{c} \pm 0.05$ & $151.45^{\mathrm{e}} \pm 0.01$ & $0.24^{p} \pm 0.10$ & $32.50^{d} \pm 0.08$ & $0.4^{c} \pm 0.03$ \\
\hline
\end{tabular}

Table 2: Physical properties of bread from blends of HQCF and wheat flour. 
98/87164 at 40 mins proofing having the highest value while the $50 \%$ TMS $98 / 8082$ at 70 mins proofing had the least value. The specific volume also increased with a reduction in the level of cassava flour substitution. Specific volume which is the ratio of loaf weight and loaf volume has been generally adopted in literature as a more reliable measure of loaf size [20]. Consumers are often attracted by the size of the loaf by its weight and volume believing that it has more substance for the same price.

\section{Loaf volume}

The loaf volume varies significantly from $305-615 \mathrm{~cm}^{3}$ with sample B5070 having the least value while sample E2050 had the highest. It was also observed that at 10 to $20 \%$ substitution of cassava flour TME 419, TMS 98/1632 and TMS98/87164, the loaf volume increased significantly $(\mathrm{p}<0.05)$ from 545 to $702 \mathrm{~cm}^{3}$, with the bread baked with $10 \%$ TMS $98 / 87164$ having the highest value $\left(702 \mathrm{~cm}^{3}\right)$ which was also the sample with the highest specific volume, while substitution level between 30 to $50 \%$ recorded a decrease in the loaf volume with the values ranging from 324 to $485 \mathrm{~cm}^{3}$. This result agrees with the findings of Oladumoye et al. [21] and Nwosu et al. [16] who reported increase in acceptance of bread loaf samples with lower concentration of cassava flour by panelists. Regae and Abdel-Aal [20] and Defloor et al. [17] reported that loaf volume is affected by the quality and quantity of protein in the flour. Cassava flour is not a good source of protein, as an increase in the substitution level resulted to a lower loaf volume as observed in bread baked with 30 to $50 \%$ which recorded values from 324 to $485 \mathrm{~cm}^{3}$ compared to a lower substitution of 10 to $20 \%$ with values from 545 to $702 \mathrm{~cm}^{3}$.

\section{Loaf weight}

The loaf weight ranged from 140.43 to $158.54 \mathrm{~g}$. The result also showed that with increased cassava flour substitution between 30 to 50\% with TMS 98/1632, TMS 98/8082 and TMS 98/87164 not considering the proofing time; a substantial increase was observed in the loaf weight. Higher loaf weight and volume have been taken to have positive economic value on the bread at the retail end. In other words, loaf weight and volume reduction during baking is an unacceptable economic quality to bakers as the populace tends to prefer bread with increased loaf weight as it is believed to have more value [22]. Cassava tends to absorb more moisture than wheat which could be the reason for the increased loaf weight. Shittu et al. [18] reported that loaf weight is affected basically by the quantity of dough baked and amount of moisture and carbon dioxide diffused out of the loaf during baking. The positive effect of the cassava variety is in line with the observation made by Almazan [6] who reported a significant genotypic effect on the cassava wheat composite bread quality especially at high flour composite.

\section{Loaf density}

The loaf density ranged from 0.24 to $0.51 \mathrm{~cm}^{3} / \mathrm{g}$ with sample E2050 having the lowest value while sample B5070 had the highest. The results also showed that with increase in the substitution level of cassava flour and longer proofing time, loaf density becomes higher suggesting that cassava flour absorbs more moisture than wheat flour. It also indicates that longer proofing time could lead to collapse of the dough after rising which will make the bread to compact together allowing no further expansion for gas evolution. This agrees with the reports of Singh et al. [23] and Zhang et al. [24] that loaf density is primarily affected by the volumetric expansion of dough due to gas evolution during proofing and that early onset of gelatinization causes faster plasticization of the starch- protein network on gas cell wall formed and increases mechanical strength of dough near the surface thereby making other expansions difficult.

\section{Crumb moisture}

Flour compositions had significant $(\mathrm{p} \leq 0.100)$ effect on the bread parameters. At a higher substitution level (30-50\%) of cassava flour an increase in the crumb moisture was observed. This could be attributed to the fact that cassava flour has the ability to retain or absorb more water than wheat flour. Also, cassava variety, flour composition and proofing time had significant ( $\mathrm{p} \leq 0.100)$ effect on the crumb moisture. Crumb moisture is determined by the extent of gelatinization of starch in the dough during baking. The amount of moisture in bread crumb has some implication on the mechanical and keeping quality of bread $[17,22]$.

\section{Oven spring}

The oven spring of the bread samples ranged from 0 to $0.8 \mathrm{~cm}$. The results also showed that at 10 to $20 \%$ inclusion of cassava flour and 40 to 50 mins proofing time, an increase in the oven spring was observed from samples baked with TME419, TMS 98/1632, TMS 98/87164 and TMS 98/8082. Some samples showed a negative result representing a collapse in the bread height. This showed that at an increased substitution level and increased time of proofing, oven spring of the bread decreased. These decreases are undesirable at the retail end as consumers prefer bread with firm height. Oven spring is the difference between the height of dough after proofing and height of loaf after baking.

\section{Sensory attributes of bread made from HQCF/wheat flour blends}

The results of the effects of cassava variety, substitution level and proofing time on the sensory attributes (loaf volume, softness of feel, crumb and crust appearance, and taste) of HQCF bread are shown in Tables 3-7.

\section{Loaf volume}

Sensory evaluation on the loaf volume (Table 3 ) showed that bread samples from $10 \%$ with TME 419 at 40 mins proofing had lower mean sensory scores (1.44) suggesting that this samples was mostly preferred by the panelists amongst other bread samples followed by bread made with $30 \%$ TMS $98 / 1632(1.52)$ at $80 \mathrm{~min}$ proofing. The reduction in the loaf volume with an increase in the substitution level was obvious as bread with $40 \%$ TMS 98/8082 at 60 mins proofing recorded the highest sensory mean score of 4.60 showing least preference by the panelists. It is well known that cassava flour lacks gluten protein which is required for leavening of dough. This result agrees with the finding of Adeyemi et al. [25] who reported a reduction in loaf volume as the substitution level increases.

\section{Softness of feel}

The results of the effect of cassava variety, substitution levels, proofing time on softness feel (texture) of bread are presented in Table 4. The sample, $10 \%$ TME 419 , at 60 mins proofing recorded the least mean sensory score of 1.08 which indicated most preferred on the ranking scale. Bread baked with $10 \%$ cassava wheat flour composite was reported not to be significantly $(\mathrm{p}<0.05)$ different in sensory attributes compared to $100 \%$ wheat flour [26-28]. Some panelist showed likeness to some bread samples baked with 20 to $30 \%$ TMS 98/1632 and TME 419 with significant sensory mean scores of 1.56 and 
Citation: Iwe MO, Michael N, Madu NE, Obasi NE, Onwuka GI, et al. (2017) Production and Evaluation of Bread Made from High Quality Cassava Flour (HQCF) and Wheat Flour Blends. Agrotechnology 6: 166. doi: 10.4172/2168-9881.1000166

Page 6 of 8

\begin{tabular}{|c|c|c|c|c|c|c|c|c|c|c|}
\hline & & $40 \mathrm{~min}$ & & $50 \mathrm{~min}$ & & $60 \mathrm{~min}$ & & $70 \min$ & & $80 \min$ \\
\hline Sample & $\begin{array}{c}\text { Subst. } \\
\text { Level\% } \\
\text { Cassava: } \\
\text { Wheat }\end{array}$ & Mean & $\begin{array}{c}\text { Subst. } \\
\text { Level\% } \\
\text { Cassava: } \\
\text { Wheat }\end{array}$ & Mean \& std & $\begin{array}{c}\text { Subst. } \\
\text { Level\% } \\
\text { Cassava: } \\
\text { Wheat }\end{array}$ & Mean \& std & $\begin{array}{c}\text { Subst. } \\
\text { Level\% } \\
\text { Cassava: } \\
\text { Wheat }\end{array}$ & Mean \& std & $\begin{array}{c}\text { Subst. } \\
\text { Level\% } \\
\text { Cassava: } \\
\text { Wheat }\end{array}$ & Mean \& std \\
\hline 8082 & $30: 70$ & $4.92^{a} \pm 0.28$ & $40: 60$ & $3.72^{\mathrm{a}} \pm 0.48$ & $40: 60$ & $4.60^{a} \pm 0.91$ & $50: 50: 00$ & $3.96^{a} \pm 1.4$ & 50:50:00 & $2.76^{b} \pm 1.13$ \\
\hline 581 & $30: 70$ & $4.04^{b} \pm 0.35$ & 0.8888889 & $3.72^{\mathrm{a}} \pm 1.54$ & $40: 60$ & $3.16^{b} \pm 1.28$ & $50: 50: 00$ & $3.68^{\mathrm{ab}} \pm 1.15$ & $50: 50: 00$ & $3.76^{a} \pm 0.93$ \\
\hline 87164 & 0.4791667 & $3.00^{c} \pm 0.29$ & 0.8888889 & $3.32^{\mathrm{a}} \pm 1.07$ & $30: 70$ & $2.24^{c} \pm 0.78$ & $40: 60$ & $3.24^{b} \pm 0.85$ & $50: 50: 00$ & $4.08^{a} \pm 1.32$ \\
\hline 1632 & 0.4791667 & $1.60^{\text {cd }} \pm 0.5$ & 0.4791667 & $2.28^{\mathrm{b}} \pm 1.24$ & 0.8888889 & $2.24^{c} \pm 1.72$ & 0.8888889 & $1.84^{\mathrm{c}} \pm 1.34$ & $30: 70$ & $1.52^{c} \pm 1.16$ \\
\hline 419 & 0.4791667 & $1.44^{d} \pm 0.58$ & 0.4791667 & $1.94^{b} \pm 1.24$ & 0.8888889 & $2.72^{\mathrm{bc}} \pm 0.68$ & 0.8888889 & $2.28^{c} \pm 1.06$ & $30: 70$ & $2.86^{b} \pm 1.01$ \\
\hline LSD & - & 0.178 & - & 0.283 & - & 0.163 & - & 0 & - & 0.313 \\
\hline
\end{tabular}

Values are means \pm standard deviation of duplicate determinations.

Means bearing the different superscript down the row are significantly different $(p \leq 0.05)$.

Table 3: Effect of cassava variety, substitution level and proofing time on loaf volume of HQCF bread.

\begin{tabular}{|c|c|c|c|c|c|c|c|c|c|c|}
\hline & & $40 \mathrm{~min}$ & & $50 \mathrm{~min}$ & & $60 \mathrm{~min}$ & & $70 \mathrm{~min}$ & & $80 \mathrm{~min}$ \\
\hline Sample & $\begin{array}{c}\text { Subst. } \\
\text { Level\% } \\
\text { Cassava: } \\
\text { Wheat }\end{array}$ & Mean & $\begin{array}{c}\text { Subst. } \\
\text { Level\% } \\
\text { Cassava: } \\
\text { Wheat }\end{array}$ & Mean \& std & $\begin{array}{l}\text { Subst. } \\
\text { Level\% } \\
\text { Cassava: } \\
\text { Wheat }\end{array}$ & $\begin{array}{l}\text { Mean } \\
\text { \&std }\end{array}$ & $\begin{array}{l}\text { Subst. } \\
\text { Level\% } \\
\text { Cassava: } \\
\text { Wheat }\end{array}$ & Mean \&std & $\begin{array}{c}\text { Subst. } \\
\text { Level\% } \\
\text { Cassava: } \\
\text { Wheat }\end{array}$ & Mean \&std \\
\hline 8082 & $30: 70$ & $4.00^{\mathrm{a}} \pm 1.01$ & $40: 60$ & $3.84^{b} \pm 1.01$ & $40: 60$ & $4.88^{a} \pm 0.44$ & $50: 50: 00$ & $3.32^{b} \pm 0.85$ & $50: 50: 00$ & $3.8^{\mathrm{b}} \pm 0.87$ \\
\hline 581 & $30: 70$ & $3.68^{\mathrm{a}} \pm 1.14$ & 0.8888889 & $4.60^{\mathrm{a}} \pm 1.35$ & $40: 60$ & $3.92^{b} \pm 0.4$ & $50: 50: 00$ & $4.32^{\mathrm{a}} \pm 1.01$ & $50: 50: 00$ & $4.84^{a} \pm 0.37$ \\
\hline 87164 & 0.4791667 & $3.76^{a} \pm 1$ & 0.8888889 & $2.24^{d} \pm 1.11$ & $30: 70$ & $2.32^{d} \pm 0.69$ & $40: 60$ & $4.12^{\mathrm{ab}} \pm 0.53$ & $50: 50: 00$ & $2.68^{c} \pm 0.8$ \\
\hline 1632 & 0.4791667 & $1.72^{\mathrm{b}} \pm 0.84$ & 0.4791667 & $2.60^{c} \pm 0.86$ & 0.8888889 & $2.80^{c} \pm 0.76$ & 0.8888889 & $1.56^{c} \pm 0.87$ & $30: 70$ & $2.24^{\mathrm{d}} \pm 0.8$ \\
\hline 419 & 0.4791667 & $1.84^{b} \pm 1.03$ & 0.4791667 & $1.72^{\mathrm{e}} \pm 0.84$ & 0.8888889 & $1.08^{e} \pm 0.28$ & 0.8888889 & $1.68^{c} \pm 0.56$ & $30: 70$ & $1.44^{\mathrm{e}} \pm 0.82$ \\
\hline LSD & - & 0.678 & - & 0.29 & - & 1 & - & 0.38 & - & 1 \\
\hline
\end{tabular}

Table 4: Effect of cassava variety, substitution level and proofing time on softness of feel.

\begin{tabular}{|c|c|c|c|c|c|c|c|c|c|c|}
\hline & Subst. & $40 \mathrm{~min}$ & Subst. & $50 \mathrm{~min}$ & Subst. & $60 \mathrm{~min}$ & Subst. & $70 \mathrm{~min}$ & Subst. & $80 \mathrm{~min}$ \\
\hline Sample & Level\% & Mean & Level\% & Mean \& std & Level\% & Mean & Level\% & Mean \&std & Level\% & Mean \& std \\
\hline 8082 & $30: 70$ & $3.56^{a} \pm 0.91$ & 40 & $3.72^{a} \pm 1.43$ & $40: 60$ & $3.40^{\mathrm{a}} \pm 1.19$ & $50: 50: 00$ & $3.92^{\mathrm{a}} \pm 1.44$ & 50 & $3.52^{\mathrm{a}} \pm 1.29$ \\
\hline 581 & $30: 70$ & $3.52^{\mathrm{a}} \pm 1.53$ & 20 & $3.48^{\mathrm{ab}} \pm 1.16$ & $40: 60$ & $3.12^{\mathrm{a}} \pm 1.48$ & $50: 50: 00$ & $3.04^{b} \pm 1.06$ & 50 & $3.16^{\mathrm{a}} \pm 1.28$ \\
\hline 87164 & 0.4791667 & $3.32^{\mathrm{a}} \pm 1.63$ & 20 & $2.84^{\mathrm{bc}} \pm 1.28$ & $30: 70$ & $2.92^{\mathrm{a}} \pm 1.41$ & $40: 60$ & $2.84^{b} \pm 1.4$ & 50 & $3.08^{\mathrm{a}} \pm 1.49$ \\
\hline 1632 & 0.4791667 & $2.36^{b} \pm 1.04$ & 10 & $2.48^{c} \pm 1.33$ & 0.8888889 & $3.0^{a} \pm 1.47$ & 0.8888889 & $2.60^{\mathrm{b}} \pm 1.63$ & 30 & $3.04^{\mathrm{a}} \pm 1.43$ \\
\hline 419 & 0.4791667 & $2.24^{b} \pm 1.33$ & 10 & $2.48^{\mathrm{c}} \pm 1.5$ & 0.8888889 & $2.56^{\mathrm{a}} \pm 1.5$ & 0.8888889 & $2.60^{b} \pm 1.54$ & 30 & $2.20^{b} \pm 1.35$ \\
\hline LSD & & 0.55 & & 0.53 & & 0.63 & & 0.3 & & 0.27 \\
\hline
\end{tabular}

Values are means \pm standard deviation of duplicate determinations.

Means bearing the different superscript down the row are significantly different $(p \leq 0.05)$.

Table 5: Effect of cassava variety, substitution level and proofing time on crumb appearance.

\begin{tabular}{|c|c|c|c|c|c|c|c|c|c|c|}
\hline & & $40 \mathrm{~min}$ & & $50 \mathrm{~min}$ & & $60 \mathrm{~min}$ & & $70 \mathrm{~min}$ & & $80 \mathrm{~min}$ \\
\hline Sample & $\begin{array}{c}\text { Subst. } \\
\text { Level\% } \\
\text { Cassava: } \\
\text { Wheat }\end{array}$ & Mean \& std & $\begin{array}{c}\text { Subst. } \\
\text { Level\% } \\
\text { Cassava: } \\
\text { Wheat }\end{array}$ & Mean \& std & $\begin{array}{c}\text { Subst. } \\
\text { Level\% } \\
\text { Cassava: } \\
\text { Wheat }\end{array}$ & $\begin{array}{l}\text { Mean } \\
\& \text { std }\end{array}$ & $\begin{array}{c}\text { Subst. } \\
\text { Level\% } \\
\text { Cassava: } \\
\text { Wheat }\end{array}$ & Mean \& std & $\begin{array}{c}\text { Subst. } \\
\text { Level\% } \\
\text { Cassava: } \\
\text { Wheat }\end{array}$ & Mean \& std \\
\hline 8082 & $30: 70$ & $3.32^{\mathrm{ab}} \pm 0.98$ & $40: 60$ & $3.48^{\mathrm{ab}} \pm 1.38$ & $40: 60$ & $3.56^{a} \pm 1.38$ & $50: 50: 00$ & $3.88^{a} \pm 1.42$ & $50: 50: 00$ & $2.84^{a} \pm 1.01$ \\
\hline 581 & $30: 70$ & $3.72^{\mathrm{a}} \pm 1.24$ & 0.8888889 & $4.12^{\mathrm{a}} \pm 1.12$ & $40: 60$ & $3.44^{\mathrm{ab}} \pm 0.96$ & $50: 50: 00$ & $2.92^{\mathrm{bc}} \pm 1.46$ & $50: 50: 00$ & $3.48^{a} \pm 1.78$ \\
\hline 87164 & 0.4791667 & $3.00^{\mathrm{ab}} \pm 1.73$ & 0.8888889 & $2.84^{b c} \pm 1.24$ & $30: 70$ & $3.60^{\mathrm{a}} \pm 1.22$ & $40: 60$ & $2.88^{\mathrm{bc}} \pm 1.16$ & $50: 50: 00$ & $3.04^{a} \pm 1.09$ \\
\hline 1632 & 0.4791667 & $2.24^{c} \pm 1.33$ & 0.4791667 & $\begin{array}{r}2.36^{c} \\
1.25\end{array}$ & 0.888888889 & $2.76^{b} \pm 1.3$ & 0.8888889 & $3.16^{\mathrm{ab}}$ & $30: 70$ & $2.96^{a} \pm 1.01$ \\
\hline 419 & 0.4791667 & $2.72^{\mathrm{bc}} \pm 1.33$ & 0.4791667 & $2.20^{c} \pm 1.19$ & 0.888888889 & $1.64^{\mathrm{c}} \pm 1.22$ & 0.8888889 & $2.16^{c} \pm 1.34$ & $30: 70$ & $2.68^{a} \pm 1.54$ \\
\hline LSD & - & 0.53 & - & 0.5 & - & 0.60 & 0.7 & 0.55 & - & 0.62 \\
\hline
\end{tabular}

Values are means \pm standard deviation of duplicate determinations.

Means bearing the different superscript down the row are significantly different $(p \leq 0.05)$.

Table 6: Effect of cassava variety, substitution level and proofing time on crust appearance.

1.44 at 70 and 80 mins proofing respectively. Inclusion of cassava flour into wheat flour up to about $30 \%$ could still give an acceptable fresh loaf probably owing to personal choice and appearance [17,29]. The high supplementation of non-wheat flour showed high sensory score of 4.88 with the bread sample with $40 \%$ TMS $98 / 8082$ at 60 mins proofing time. High substitution of cassava flour reduces elasticity properties of wheat flour dough making the dough incapable of retaining the gas emanating from fermentation [30].

\section{Crumb appearance}

Bread baked with $30 \%$ TME 419 at 80 min proofing time had the least sensory mean score of 2.20 (Table 5) and was most preferred by 
Citation: Iwe MO, Michael N, Madu NE, Obasi NE, Onwuka GI, et al. (2017) Production and Evaluation of Bread Made from High Quality Cassava Flour (HQCF) and Wheat Flour Blends. Agrotechnology 6: 166. doi: 10.4172/2168-9881.1000166

Page 7 of 8

\begin{tabular}{|c|c|c|c|c|c|c|c|c|c|c|}
\hline & & $40 \mathrm{~min}$ & & $50 \mathrm{~min}$ & & $60 \mathrm{~min}$ & & $70 \mathrm{~min}$ & & $80 \mathrm{~min}$ \\
\hline Sample & $\begin{array}{l}\text { Subst. } \\
\text { Level\% } \\
\text { Cass:W }\end{array}$ & Mean & $\begin{array}{l}\text { Subst. } \\
\text { Level\% } \\
\text { Cass:W }\end{array}$ & Mean \& std & $\begin{array}{l}\text { Subst. } \\
\text { Level\% } \\
\text { Cass:W }\end{array}$ & $\begin{array}{l}\text { Mean } \\
\text { \&std }\end{array}$ & $\begin{array}{l}\text { Subst. } \\
\text { Level\% } \\
\text { Cass:W }\end{array}$ & Mean \&std & $\begin{array}{l}\text { Subst. } \\
\text { Level\% } \\
\text { Cass:W }\end{array}$ & Mean \& std \\
\hline 8082 & $30: 70$ & $3.12^{\mathrm{ab}} \pm 1.39$ & $40: 60$ & $3.28^{\mathrm{a}} \pm 1.74$ & $40: 60$ & $3.12^{\mathrm{ab}} \pm 1.33$ & $50: 50: 00$ & $2.92^{\mathrm{a}} \pm 1.44$ & $50: 50: 00$ & $3.04^{\mathrm{a}} \pm 1.17$ \\
\hline 581 & $30: 70$ & $3.28^{a} \pm 1.49$ & 0.8888889 & $2.96^{\mathrm{a}} \pm 1.48$ & $40: 60$ & $3.80^{\mathrm{a}} \pm 1.47$ & $50: 50: 00$ & $3.16^{\mathrm{a}} \pm 1.49$ & $50: 50: 00$ & $3.33^{a} \pm 1.46$ \\
\hline 87164 & 0.4791667 & $3.20^{\mathrm{ab}} \pm 1.56$ & 0.8888889 & $2.84^{\mathrm{a}} \pm 1.21$ & $30: 70$ & $3.04^{\mathrm{ab}} \pm 1.31$ & $40: 60$ & $3.04^{a} \pm 1.54$ & $50: 50: 00$ & $3.36^{\mathrm{a}} \pm 1.47$ \\
\hline 1632 & 0.4791667 & $3.04^{\mathrm{ab}} \pm 1.24$ & 0.4791667 & $3.16^{a} \pm 1.52$ & 0.888888889 & $2.72^{\mathrm{ab}} \pm 1.2$ & 0.888888889 & $2.88^{a} \pm 1.42$ & $30: 70$ & $2.64^{\mathrm{a}} \pm 1.52$ \\
\hline 419 & 0.4791667 & $2.36^{b} \pm 1.31$ & 0.4791667 & $2.76^{a} \pm 1.1$ & 0.888888889 & $2.32^{\mathrm{b}} \pm 1.43$ & 0.8888888889 & $2.92^{\mathrm{a}} \pm 1.42$ & $30: 70$ & $2.60^{\mathrm{a}} \pm 1.38$ \\
\hline LSD & - & 0.05 & - & 0.26 & - & 0.057 & - & 0.559 & - & 0.091 \\
\hline
\end{tabular}

Values are means \pm standard deviation of duplicate determinations

Means bearing the different superscript down the row are significantly different $(p \leq 0.05)$.

Table 7: Effect of cassava variety, substitution level and proofing time on Taste.

the panelists followed by bread from 10\% TME 419 (2.24) at $40 \mathrm{~min}$ proofing and bread baked with 10\% TMS 98/1632 (2.36) at $40 \mathrm{~min}$ proofing time while bread from 50\% TMS 8082 at 70 min proofing had the highest sensory mean score of 3.88. However, preference decreased with increased cassava flour inclusion. The amount of moisture in bread crumb has some implications on the mechanical [22] and keeping quality [17].

\section{Crust appearance}

Table 6 shows that bread samples with 20\% TME 419 at 60 min proofing with the sensory mean score of 1.64 was mostly preferred by panelists in terms of crust appearance followed by sample with $10 \%$ TMS 98/1632 (2.24). Bread crust color is an important sensory attribute which can enhance acceptability. The local population thinks that pale colored bread crust is indicative of improper baking. Moreover, it is assumed that the brown color is what impacts nutrient, especially, iron on the product. Crust appearance depreciated as substitution level increased. The preference of bread crust color of the samples with lower substitution level of cassava flour could be due to the presence of gluten protein from wheat flour and some reducing sugars in cassava flour, as an increase in cassava flour reduces the wheat flour and allows retention of more moisture in the dough causing paleness of the bread crust when baked. This agrees with the observation made by Dendy [31] that brownness of bread crust emanates from the Maillard reaction during baking in the presence of amino acids, reducing sugar, temperature, time of baking and moisture levels of the fermented dough. Color is also an inevitable check that could be used in determining the effects of ingredients or product formulation, process variable as well as the storage condition on baked products [32-34].

\section{Taste}

Table 7 shows that bread baked with 20\% TME 419 at $60 \mathrm{~min}$ proofing with the sensory score of 2.23 was significantly preferred by the panelists followed by bread with $10 \%$ TME 419 at 40 min proofing. Taste is an important sensory attribute of any food [14]. Consumption of food is often enhanced by taste [35]. However, some panelists still expressed likeness for samples with high level of substitution of cassava flour such as bread from 30\% TME 419 at $80 \mathrm{~min}$ proofing and $30 \%$ TMS 98/1632 bread with sensory mean scores of 2.60 and 2.64 respectively. This observation may be attributed to personal choices as reported by Khalil et al. [36] who stated that inclusion of cassava flour into wheat flour up to $30 \%$ could still give some desirable physical and sensory characteristics.

\section{Conclusion}

From the results obtained from this study, it can be concluded that high quality cassava flour (HQCF) can be used as a partial replacement for wheat flour in bread baking. HQCF/wheat flour composites between $10-30 \%$ of cassava flour at proofing time between 40-50 mins using flour from cassava varieties TMS 98/87164, TME 98/419 and TMS 98/1632 gave the best desirable physical and sensory attributes. The bread samples were highly rated and mostly preferred by the panelists. However, bread baked with cassava flour composition between 40$50 \%$ at proofing time between $60-80$ mins and with cassava varieties NR98/8082 and TMS 98/0581 had very poor physical properties as well as low sensory attributes. This implies that replacement of wheat flour by HQCF beyond $30 \%$ substitution is not desirable.

\section{Acknowledgment}

We acknowledge the provision of funds, support and supervision through The Royal Institution for the Advancement of Learning/McGill University, 845 Sherbrooke Street West, Montréal, QC, H3A 0G4, and role of facilitation by the International Institute for Tropical Agriculture, Ibadan (IITA) Nigeria.

\section{References}

1. Olaoye OA, Onilude AA, Idowu OA (2006) Quality Characteristics of Bread produced from composite flours of wheat, plantain and soybeans. Afr $J$ Biotechnol 5: 1102-1106.

2. Iwe MO, Okereke GO, Agiriga AN (2014) Production and Evaluation of Bread Made from Modified Cassava Starch and Wheat Flour Blends. Agrotechnol 4: 133.

3. Iwe MO, Agiriga AN (2015) Effect of Different Harvesting Regimes on the Pasting Properties of Selected Varieties of Banana - A Response Surface Study. Agrotechnol 4: 132.

4. Falade KO, Akingbala JO (2008) Improved nutrition and national development through the utilization of Cassava in baked foods. In: Robertson GL, Lupien JR (eds.) Int Union Food Sci Technol.

5. Adetuyi FO, Badejo OF, Ikujenlola AV, Omosuli SV (2009) Storage influence on the functional properties of malted and unmalted maize (Zea mays $L$ ssp mays) and soybean (Glycine max L Merrill) flour blends. Afr J Food Sci 3: 56-60.

6. Almazan AM (1990) Effect of cassava flour variety and concentration on bread loaf quality. Cereal chem 67: 97.

7. Adeboye AS, Babajide JM, Shittu TA, Omemu AM, Oluwatola OJ (2013) Effect of honey as partial sugar substitute on pasting properties, consumer preference and shelf stability of cassava-wheat composite bread. Nig Food J 31: 13-22.

8. IITA (2006) Cassava Recipes for Household Food Security. Internationa Institute of Tropical Agriculture (IITA). Pp: 10-25.

9. Eggleston G, Omoaka PE, Arowosegbe AU (1993) Flour, Starch and Composite Breadmaking Qualityof Various Clones. J Sci Food Agric 62: 49-59.

10. Horwitz W (1975) Official methods of analysis Washington DC: Association of Official Analytical Chemists.

11. AACC (2000) Approved Methods of the American Association of Cereal Chemists. American Association of Cereal Chemists, Inc; St. Paul, Minnesota, USA.

12. Ihekoronye Al, Ngoddy PO (1985) Integrated food science and technology for the tropics. Macmillan.

13. Onwuka GI (2005) Food Analysis and Instrumentation. Naphtali Publishers, Lagos Nigeria. 
Citation: Iwe MO, Michael N, Madu NE, Obasi NE, Onwuka GI, et al. (2017) Production and Evaluation of Bread Made from High Quality Cassava Flour (HQCF) and Wheat Flour Blends. Agrotechnology 6: 166. doi: 10.4172/2168-9881.1000166

Page 8 of 8

14. Iwe MO (2010) Handbook of sensory methods and analysis. Rojoint communication services Ltd, Uwani-Enugu Nigeria.

15. Warner M, Thiel BL, Donald AM (2000) The Elasticity and failure of fluid-filled cellular solids. Proceedings of the National Academy of Science 97: 1370-1375.

16. Nwosu JN, Owuamanam Cl, Omeire GC, Eke CC (2014) Quality parameters of bread produced from substitution of wheat flour with cassava flour using soybean as an improver. Am J Res Comm 2: 99-118.

17. Defloor I (1995) Factors governing the breadmaking potential of cassava (Manihot esculenta Crantz) flour. Dissertationes de Agricultura.

18. Shittu TA, Raji AO, Sanni LO (2007) Bread from composite cassava-wheat flour: I. Effect of baking time and temperature on some physical properties of bread loaf. Food Res Int 40: 280-290.

19. Abass AB, Onabolu AO, Bokanga M (1998) Impact of the high-quality cassava flour technology in Nigeria. In root crops in the 21 st century. Proceedings of the 7th Triennial Symposium of the International Society for Tropical Root Crops- Africa Branch (ISTRC-AB). Centre International des Conferences, Cotonou, Benin.

20. Ragaee S, Abdel-Aal ESM (2006) Pasting properties of starch and protein in selected cereals and quality of their products. Food Chem 95: 9-18.

21. Oladunmoye OO, Akinoso R, Olapade AA (2010) Evaluation of some physical-chemical properties of wheat, cassava, maize and cowpea flours for breadmaking. J Food Quality 33: 693-708.

22. Zghal MC, Scanlon MG, Sapirstein HD (2002) Cellular structure of bread crumb and its influence on mechanical properties. J Cereal Chem 36: 167-176.

23. Singh RP, Heldman DR, See EF (2011) Introduction to Food Engineering, Academic Press. San Diego, CA. USA, Pp: 565-567.

24. Zhang J, Datta AK (2006) Mathematical modeling of bread baking process. J Food Eng 75: 78-89.

25. Adeyemi IA, Idowu MA (1990) Evaluation of pregelatinized maize in the development of maissa-a baked product. Nig Food J 8: 63-73.
26. Eddy NO, Udofia PG, Eyo D (2007) Sensory evaluation of wheat/cassava composite bread and effect of label information on acceptance and preference. Afr J Biotechnol 6: 123-134.

27. Aboaba OO, Obakpolor EA (2010) The leavening ability of bakers' yeast on dough prepared with composite flour (Wheat/Cassava). Afr J Food Sci 4: 325-329.

28. Eriksson E, Koch K, Tortoe C, Akonor PT, Oduro-Yeboah C (2014) Evaluation of physical and sensory characteristics of bread produced from three varieties of cassava and wheat composite flour. Food Public Health 4: 214-222.

29. Eduardo M, Svanberg U, Ahrne L (2013) Effects of cassava flour characteristics on properties of cassava-wheat-maize and boiled African bread fruit (Treculia Africana) seed. J Mat Res 1: 16-25

30. Giami GY, Amasisi T, Ekiyor G (2004). Comparison of bread making properties of composite flour from kernel of roasted and boiled African bread fruit (Treculia Africana) seed. J Mat Res 1: 16-25.

31. Dendy DAV (1992) Composite flour-past, present, and future: a review with special emphasis on the place of composite flour in the semi-arid zones. Utilization of sorghum and millets 502: 67

32. Erkan H, Celik S, Bilgi B, Koskel H (2006) A New Approach for The Utilization of Barley in Food Products: barley tarhana. Food Chem 97: 12-18.

33. Gallagher E, Kunkel A, Gormley TR, Arendt EK (2003) The effect of diary powder addition on loaf and crumb characteristics, and on shelf life (intermediate and long term) of gluten-free bread stored in a modified atmosphere. Eur J Food Res 218: $44-48$.

34. Sanchez C, Klopfenstein C, Walker CE (1995) Use of Carbohydrate fat substitute and emulsifying agents in reduced-fat shortbread cookies. Cereal Chem 72: 25-29.

35. Sim J, Nya T (2001) Eating Qualities of Muffins prepared with $10 \%$ and $30 \%$ soy flour. J Nutr Recipe Menu Dev 3: 2.

36. Khalil AH, Mansour EH, Dawood FM (2000) Influence of malt on rheological and baking properties of wheat-cassava composite flours. LWT-Food Sci Technol 33:159- 164 